\title{
Physical and chemical methods for contaminant control during the in vitro introduction and establishment of Bambusa vulgaris Schrad. ex J. C. Wendl.
}

\section{Métodos físicos e químicos para controle de contaminantes durante a introdução e estabelecimento de Bambusa vulgaris Schrad. ex J. C. Wendl. in vitro}

\author{
Gustavo Rubens de Castro TORRES ${ }^{1}$; Eurico Eduardo Pinto de LEMOS ${ }^{2}$ \\ ${ }^{1}$ Autor para correspondência. Doutorado em Fitopatologia, Centro de Tecnologias Estratégicas do Nordeste - CETENE, \\ Laboratório de Pesquisas Aplicadas à Biofábrica, Rua Professor Luiz Freire, no 1, Cidade Universitária, CEP.: 50.740-545, \\ Recife-PE, gustavorubenstorres01@gmail.com \\ ${ }^{2}$ Doutorado em Biotecnologia e Cultura de Tecidos Vegetais, Universidade Federal de Alagoas, Centro de Ciências Agrárias - \\ UFAL, eurico@ceca.ufal.br
}

Recebido em: 14-05-2017; Aceito em: 28-07-2017

\begin{abstract}
The aim of the research was to test physical and chemical methods to reduce microbial contamination during the introduction and establishment of the in vitro propagation of Bambusa vulgaris by means of two experiments. The first one was conducted in a completely randomized design in a $2 \times 2$ factorial arrangement (removal or nonremoval of leaf residues covering the bud $\times$ two types of culture medium). The second experiment was conducted in a completely randomized design in a $2 \times 3$ factorial arrangement (use or non-use of thermotherapy for nodal segments $\times$ three types of culture medium). Removal of leaf residues in the first experiment did not ensure a high sanitary level of the nodal segments, as well as thermotherapy at $50^{\circ} \mathrm{C}$ for 20 minutes in the second experiment, which affected sprouting. The liquid medium with half the concentration of salts, without sucrose, with $4 \mathrm{~mL}^{-1}$ Derosal $500 \mathrm{SC}^{\circledR}$ and $200 \mathrm{mg} \mathrm{L}^{-1}$ Chloramphenicol in the first experiment resulted in $48 \%$ of nodal segments sprouted and free of contamination, this value being of $52 \%$ in the second experiment, proving to be the most effective tested chemical method to reduce microbial contamination.
\end{abstract}

Additional keywords: antibiotic; bamboo; contamination; fungicide; micropropagation.

\section{Resumo}

O objetivo da pesquisa foi testar métodos físicos e químicos para reduzir a contaminação microbiana durante as fases de introdução e estabelecimento da propagação in vitro de Bambusa vulgaris por meio de dois experimentos. $O$ primeiro foi conduzido em delineamento inteiramente casualizado em arranjo fatorial $2 \times 2$ (remoção ou não dos resíduos da folha que cobre a gema $\times$ dois tipos de meio de cultura). $O$ segundo experimento foi conduzido em delineamento inteiramente casualizado em arranjo fatorial $2 \times 3$ (termoterapia ou não de segmentos nodais $\times$ três tipos de meio de cultura). A remoção dos resíduos da folha, no primeiro experimento, não assegurou alta taxa de sanidade dos segmentos nodais, assim como a termoterapia a $50^{\circ} \mathrm{C}$ por 20 minutos, no segundo experimento, que afetou a brotação das gemas. $\mathrm{O}$ meio líquido com metade da concentração de sais, sem sacarose, com $4 \mathrm{~mL} \mathrm{~L}^{-1}$ de Derosal $500 \mathrm{SC}^{\circledR}$ e $200 \mathrm{mg} \mathrm{L}^{-1}$ de Cloranfenicol no primeiro experimento, resultou em $48 \%$ de segmentos nodais brotados e livres de contaminação e em $52 \%$ no segundo experimento, provando ser o método químico testado mais eficaz na redução da contaminação microbiana.

Palavras-chave adicionais: antibiótico; bambu; contaminação; fungicida; micropropagação.

\section{Introduction}

Brazil is the American country with the highest potential for bamboo exploitation due to the greater diversity of species, high rate of endemic forests of this grass and for encouraging crop development through Law 12.484 of 2011, which instituted the National Policy of Incentive to Sustainable Management and Cultivation of Bamboo - PNMCB (Torres et al., 2016a).

The species Bambusa vulgaris Schrad. ex
J.C. Wendl. presents a notable prominence among those of commercial interest introduced in the national territory, being used in reforestation programs mainly in the Northeast for production of long-fiber cellulose (Tomazello Filho \& Azzini, 1987). The expression of the importance of the species in economic terms is represented by the size of the cultivated area, of 108 $\mathrm{km}^{2}$, which is distributed among the states of Maranhão, Paraíba and Pernambuco, belonging to the Industrial Group João Santos and cited as the largest 
area planted commercially with $B$. vulgaris in the world (Generoso, 2014).

Bamboo can be propagated sexually and asexually and in the latter case, traditional methods (division of clumps, rhizomes and stems) make difficult the establishment of commercial plantations, since they are laborious, expensive and of low yield. Micropropagation techniques represent an advantageous option to meet the demand for seedlings in quantity and with the same characteristics of the selected mother plant (Generoso, 2014), but present as one of the main limiting factors the microbial contaminations, since the culture media used are excellent sources of nutrients for microorganisms (Msogoya et al., 2012).

Hyde et al. (2002) report that bamboo fungi (fungi that grow on any bamboo substrate including leaves, stems, branches, rhizomes and roots) are classified as saprobic, parasitic and endophytic, and according to Torres et al. (2016a), epiphytic or endophytic microorganisms are contaminants of the in vitro micropropagation process, so that the use of antimicrobials with only superficial effect does not result in the production of aseptic propagating material and, thus, tissue infections occurring in the field can remain quiescent and microorganisms may express themselves in the form of contaminants after the in vitro introduction of explants.

Amorin \& Bergamin Filho (2006) cite in their work on basic concepts of management of quiescent diseases in fruits that integrated control is defined as a management system of harmful organisms that uses all the appropriate techniques and methods in order to maintain the populations thereof in levels below those where economic injury takes place. Therefore, considering that the process of in vitro micropropagation for production of seedlings is an advantageous economic activity, the concept of integrated control should also be considered in the case of microbial contaminants from the joint use of different methods and techniques which by additive or synergistic effect can reduce losses ensuring financial viability.

Published protocols on the in vitro culture process of different bamboo species have directed efforts to reduce microbial contamination by chemical methods such as disinfestation of explants in solutions of ethanol, sodium hypochlorite and mercury chloride, isolated or in combination, at different concentrations and time intervals in the pretreatment period (Anand et al., 2013; Jha et al., 2013; Sharma \& Sarma, 2013; Wadaktar et al., 2014).

Published works on the in vitro propagation of bamboo also cite the chemical control of contaminations by means of: a) immersion of explants, during pretreatment, in a solution of benomyl-based fungicides (Ribeiro et al.; 2016), carbendazim-based fungicides (Bavistin ${ }^{\circledR}$ ), and antibiotics such as streptocycline and rifampicin (Ali et al., 2009) or streptomycin (Arya \& Arya, 2009), in addition to mancozebe and gentamicin (Mudoi et al.; 2014) with subsequent disinfestation of the aforementioned antimicrobials and b) disinfestation using ethanol, sodium hypochlorite, calcium hypochlorite or mercury chloride and deposition in culture media containing fungicides such as benomyl (Benlate®), as reported by Ramanyake et al. (2006), and carbendazim (Derosal 500 SC $^{\circledR}$ ) associated with chloramphenicol, as reported by Torres et al. (2016a).

Chemical treatment is undoubtedly the most widespread method of controlling plant diseases, although it has the disadvantage of contaminating the environment with non-biodegradable toxic residues and the resistance acquired by microorganisms to the compounds used (Mendes et al., 2001).

Fungicides, specifically, are more preventive and less curative than physical methods that may succeed over chemical methods in cases where the latter may fail to control diseases (Groendeau \& Samson, 1994). Tokeshi (1997) cites wet heat thermotherapy as part of the practice of controlling bacterial diseases of sugarcane (Saccharum L. spp. hybrids), such as leaf scald caused by Xanthomonas albilineans (Ashby) Downson, and ratoon stunting disease by Leifsonia xyli subsp xyli [Davis et al. 1984] Evtushenko, in addition to the fungal smut disease caused by Ustilago scitaminea Sydow.

Mendes et al. (2001) describe the efficacy of dry or wet heat thermotherapy as a technique to be used in the control and/or eradication of Phoma betae Frank in beet (Beta vulgaris L.) seeds, Alternaria brassicae (Berk.) Sacc. in seeds of Brassica juncea Coss., Cercospora kikuchii (Matsumoto \& Tomoyasu) Gardner in soybean (Glycine max (L.) Merril) seeds, and Alternaria radicina Meier \& Al. in carrot (Daucus carota L.) seeds. In the case of bamboo, the above said technique is cited only in its processing as a raw material in the production of laminates, as quoted by Sharma et al. (2015), with the applicability to reduce microbial contamination in the in vitro micropropagation process remaining unknown.

In view of this scenario, the aim of the present research was to test the efficiency of physical and chemical methods in reducing the incidence of contamination during the introduction and establishment of the in vitro culture of $B$. vulgaris.

\section{Material and methods}

The research was based on two experiments conducted in a tissue culture laboratory. The first one was carried out in November 2015 and in view of the obtained results, the second one was carried out in January 2016.

Experiment I - Removal or non-removal of residues from the leaf covering the bud and composition of the introduction culture medium

The experiment was conducted in a completely randomized design in a $2 \times 2$ factorial arrangement corresponding to the combination of removal or non-removal of residues of the leaf covering the bud, which were still attached to the leaf scar, and two types of culture medium used in the introduction 
phase. The first culture medium corresponded to semisolid MS medium (Murashige \& Skoog, 1962) with half the concentration of salts, without sucrose, with $8.5 \mathrm{~g} \mathrm{~L}^{-1}$ agar (Êxodo ${ }^{\circledR}$ ), with $2 \mathrm{~mL} \mathrm{~L}^{-1}$ Plant Preservative Mixture $^{\mathrm{TM}}$, Plant Cell Technology (PPM) and without Derosal $500 \mathrm{SC}^{\circledR}$ (Concentrated Suspension of Carbendazim $500 \mathrm{~g} \mathrm{~L}^{-1}$, Bayer S/A) and Chloramphenicol, termed semi-solid introduction medium. The second culture medium corresponded to liquid MS medium with the same composition as the first except for being agar-free and containing $4 \mathrm{~mL} \mathrm{~L}^{-1}$ Derosal 500 SC$^{\circledast}$ and $200 \mathrm{mg} \mathrm{L}^{-1}$ Chloramphenicol, called liquid introduction medium.

The above said experiment was composed of four treatments with five replicates corresponding to five test tubes for the semi-solid introduction medium and five flasks for the liquid introduction medium. Each replicate consisted of a nodal segment with a single bud from primary branch per test tube containing 20 $\mathrm{mL}$ of the semi-solid introduction medium or flask containing $20 \mathrm{~mL}$ of the liquid introduction medium, totaling 25 nodal segments per treatment.

The primary branches were selected to contain a mean number of 12 swollen and nonsprouted buds as indicated by Torres et al. (2016b), and collected in the first hours of the morning in the central third of two-year-aged stems, identified as to age by the coloration of the epidermis according to Nath et al. (2008), issued from a clump of $B$. vulgaris over 40 years old, located in the neighborhood of Várzea, Recife-PE ( $8^{\circ} 32$ ' 26.16" South latitude and $34^{\circ} 58^{\prime} 27.56$ " West longitude).

The selected branches were taken to the laboratory, subjected to manual removal of the leaves covering the buds and sectioned as indicated by Torres et al. (2016a), from which the nodal segments containing the most central buds, from the fourth to the eighth position, would be obtained. For this purpose, the first bud of the branch was counted as the most apical one from which the covering leaf was eliminated manually without resistance.

The pieces of branches containing the most central buds were cut into nodal segments (called explants) presenting $2 \mathrm{~cm}$ of internode below the leaf scar and $2 \mathrm{~cm}$ of internode above the bud. Half of the total amount of nodal segments obtained was randomly separated and had leaf residues still trapped in the leaf scar region removed with the aid of a scalpel (Figure 1).

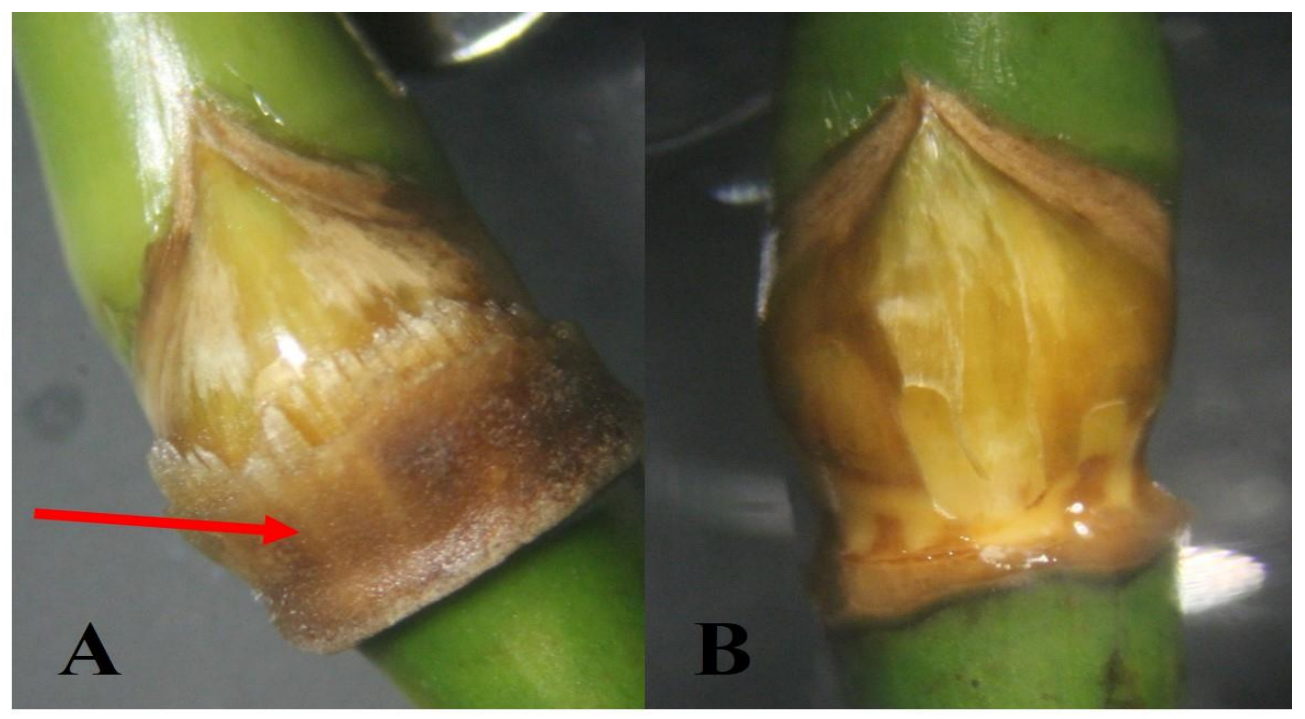

Figure 1 - Nodal region of nodal segments of Bambusa vulgaris in A) with leaf residues that covered part of the node and bud region (red arrow) and in B) without the residue of the leaf removed with a scalpel.

The explants with removal or non-removal of leaf residues were randomly divided into two groups each, so as to totalize four groups of 25 explants, which were separately deposited in flasks and immersed in $1 \%$ benzalkonium chloride solution for 10 minutes under stirring, being subsequently rinsed twice in sterile distilled water under stirring for 1 minute each and then immersed in Derosal $500 \mathrm{SC}^{\circledR}\left(4 \mathrm{~mL} \mathrm{~L}^{-1}\right)$ and Chloramphenicol (200 $\left.\mathrm{mg} \mathrm{L}^{-1}\right)$ solution under stirring for one hour and rinsed once in sterile distilled water for 1 minute. After this period, chemical disinfestation was performed in a laminar flow chamber according to Torres et al. (2016a), followed by immersion in $70 \%$ ethanol solution (water: alcohol, v:v) for $3 \mathrm{~min}$, immersion in $1 \%$ (v:v) sodium hypochlorite solution for $10 \mathrm{~min}$, rinse in sterile distilled water once for $1 \mathrm{~min}$ and then immersion in $1 \%$ sodium hypochlorite solution (v:v) for 10 min followed by three consecutive rinses in sterile distilled water for 1 min each. After disinfestation, $1 \mathrm{~mm}$ from the lower and upper parts of each explant was cut to eliminate tissues still under the influence of absorbed sodium hypochlorite, according to Jiménez et al. (2006).

The first 25 explants not subjected to removal of leaf residues were individually deposited vertically, with the bud apex facing upwards in test tubes contain- 
ing $20 \mathrm{~mL}$ of semi-solid introduction medium so that the leaf scar region entered in contact with the medium (treatment I). The remaining 25 explants not subjected to removal of leaf residues were individually deposited in flasks containing $20 \mathrm{~mL}$ of liquid introduction medium (treatment II). The same procedures were adopted in the case of the two groups of 25 explants subjected to removal of leaf residues (treatments III and IV, respectively).

The test tubes and flasks, properly closed with a lid, were kept in a growth room at $24 \pm 2{ }^{\circ} \mathrm{C}$, with a 16-hour photoperiod under $32 \mu \mathrm{mol} \mathrm{m} \mathrm{m}^{-2} \mathrm{~s}^{-1}$ luminosity provided by cold white fluorescent lamps. Seven days after the beginning of the experiment, all explants from all treatments were transferred individually into test tubes with $20 \mathrm{~mL}$ of semi-solid MS culture medium containing: total salt concentration, $30 \mathrm{~g} \mathrm{~L}^{-1}$ sucrose, $8.5 \mathrm{~g} \mathrm{~L}^{-1}$ agar, $0.5 \mathrm{mg} \mathrm{L}^{-1} \mathrm{~N}^{6}$-Benzylaminopurine, Sigma $^{\circledR}$ (BAP), $2 \mathrm{~mL}^{-1} \quad \mathrm{PPM}$ and $1 \mathrm{~g} \mathrm{~L}^{-1}$ Polyvinylpyrrolidone, Aldrich ${ }^{\circledR}$ (PVP), termed establishment medium.

An evaluation was carried out 25 days after the establishment of the experiment to count the number of explants: with fungal contamination, with bacterial contamination, sprouted, number of shoots per explant, and number of sprouted and healthy explants sent to the multiplication stage. Data were submitted to analysis of variance and the means were compared by the Duncan test at $5 \%$ level of error probability. The treatments that presented the best performance in terms of the number of sprouted and healthy explants sent to the multiplication stage were used in combination or not with thermotherapy to perform the second experiment (Experiment II).

Experiment II - Thermotherapy of explants and composition of the introduction culture medium

The experiment was conducted in a completely randomized design in a $2 \times 3$ factorial arrangement corresponding to the use or non-use of thermotherapy of nodal segments and three types of culture medium used in the introduction phase.

The culture media used showed, in common: half of the salt concentration described by Murashige and Skoog (1962), $2 \mathrm{~mL} \mathrm{~L}^{-1}$ PPM and free of sucrose; and differed as to the physical state in liquid or semisolid when added $8.5 \mathrm{~g} \mathrm{~L}^{-1}$ agar, thus being called liquid and semi-solid MS introduction medium, respectively. Also in the case of the liquid MS introduction medium, this was supplemented or not with Derosal $500 \quad \mathrm{SC}^{\circledR} \quad\left(4 \mathrm{~mL} \mathrm{~L}^{-1}\right)$ and Chloramphenicol $\left(200 \mathrm{mg} \mathrm{L}^{-1}\right)$. In this way, the combinations between the exposure or not of explants to thermotherapy and the three types of culture medium were the treatments, described in Table 1, each composed of 25 replicates, corresponding to 25 explants deposited individually in test tubes or flasks containing $20 \mathrm{~mL}$ of introduction medium (semi-solid or liquid, respectively).

Table 1 - Treatments of the Experiment II.

\begin{tabular}{|c|c|}
\hline Treatment & Description \\
\hline I & $\begin{array}{l}\text { Explants not subjected to thermotherapy in test tubes containing } 20 \mathrm{~mL} \text { of semi-solid aMS } \\
\text { introduction medium without }{ }^{b} \text { Derosal } 500 \mathrm{SC}^{\circledR} \text { and Chloramphenicol. }\end{array}$ \\
\hline II & $\begin{array}{l}\text { Explants subjected to thermotherapy in test tubes containing } 20 \mathrm{~mL} \text { of semi-solid } \mathrm{MS} \\
\text { introduction medium without Derosal } 500 \mathrm{SC}^{\circledR} \text { and Chloramphenicol. }\end{array}$ \\
\hline III & $\begin{array}{l}\text { Explants not subjected to thermotherapy in flasks containing } 20 \mathrm{~mL} \text { of liquid } \mathrm{MS} \text { introduction } \\
\text { medium with } 4 \mathrm{~mL} \mathrm{~L}^{-1} \text { Derosal } 500 \mathrm{SC}^{\circledR} \text { and } 200 \mathrm{mg} \mathrm{L}^{-1} \text { Chloramphenicol. }\end{array}$ \\
\hline IV & $\begin{array}{l}\text { Explants subjected to thermotherapy in flasks containing } 20 \mathrm{~mL} \text { of liquid } \mathrm{MS} \text { introduction } \\
\text { medium without Derosal } 500 \mathrm{SC}^{\circledR} \text { and Chloramphenicol. }\end{array}$ \\
\hline V & $\begin{array}{l}\text { Explants subjected to thermotherapy in flasks containing } 20 \mathrm{~mL} \text { of liquid MS introduction } \\
\text { medium with } 4 \mathrm{~mL} \mathrm{~L}^{-1} \text { Derosal } 500 \mathrm{SC}^{\circledR} \text { and } 200 \mathrm{mg} \mathrm{L}^{-1} \text { Chloramphenicol. }\end{array}$ \\
\hline VI & $\begin{array}{l}\text { Explants not subjected to thermotherapy in flasks containing } 20 \mathrm{~mL} \text { of liquid } \mathrm{MS} \text { introduction } \\
\text { medium without Derosal } 500 \mathrm{SC}^{\circledR} \text { and Chloramphenicol. }\end{array}$ \\
\hline \multicolumn{2}{|r|}{$\begin{array}{l}\text { aMS - culture medium with half the salt concentration described by Murashige \& Skoog (1962), free of sucrose and with } \\
2 \mathrm{~mL} \mathrm{~L}^{-1} \text { Plant Preservative Mixture (PPM); berosal } 500 \mathrm{SC}^{\circledR} \text { - concentrated suspension of Carbendazim } 500 \mathrm{~g} \mathrm{~L}^{-1} \text {. }\end{array}$} \\
\hline $\begin{array}{l}\text { The } \\
\text { same clump } \\
\text { lecting and } \\
\text { described in } \\
\text { leaf residues } \\
\text { The }\end{array}$ & $\begin{array}{l}\text { flasks and immersed in mineral water. Three of the six } \\
\text { groups of explants were subjected to bain-marie, } \\
\text { exposed to } 50^{\circ} \mathrm{C} \text { for } 20 \text { minutes and then natural cool- } \\
\text { ing for } 10 \text { minutes, undergoing the same procedures } \\
\text { performed with the explants from experiment I for pre- } \\
\text { treatment and chemical disinfestation. In a laminar flow } \\
\text { chamber, these were deposited separately in the }\end{array}$ \\
\hline
\end{tabular}


following introduction media: semi-solid without Derosal $500 \mathrm{SC}^{\circledR}$ and Chloramphenicol, liquid without Derosal $500 \mathrm{SC}^{\circledR}$ and Chloramphenicol, and liquid with $4 \mathrm{~mL} \mathrm{~L}^{-1}$ Derosal $500 \mathrm{SC}^{\circledR}$ and $200 \mathrm{mg} \mathrm{L}^{-1}$ Chloramphenicol, constituting treatments II, IV and V, respectively, described in Table 1.

The three other groups of 25 explants were kept in mineral water at room temperature for 20 minutes without the aforementioned thermotherapy, subjected to the same procedures adopted in the pretreatment and chemical disinfestation of those explants belonging to treatments in which thermotherapy was applied, being deposited in the following introduction media: semi-solid without Derosal $500 \mathrm{SC}^{\circledR}$ and Chloramphenicol, liquid with 4 $\mathrm{mL} \quad \mathrm{L}^{-1}$ Derosal $500 \mathrm{SC}^{\circledR}$ and $200 \mathrm{mg} \mathrm{L}^{-1}$ Chloramphenicol, and liquid without Derosal $500 \mathrm{SC}^{\circledR}$ and Chloramphenicol, constituting treatments I, III and $\mathrm{VI}$, respectively, described in Table 1. The explants from treatments whose introduction medium was semisolid were introduced therein up to the leaf scar height in the same manner quoted in experiment $\mathrm{I}$.

The tubes and flasks containing explants, properly closed with a lid, were kept in a growth room at $24 \pm 2{ }^{\circ} \mathrm{C}$, with a 16-hour photoperiod under $32 \mu \mathrm{mol} \mathrm{m} \mathrm{m}^{-2} \mathrm{~s}^{-1}$ luminosity provided by cold white fluorescent lamps. Seven days after the beginning of the experiment, all explants were transferred individually to test tubes containing $20 \mathrm{~mL}$ of semi-solid medium with the same constitution of the establishment medium described in experiment I and introduced therein up to the leaf scar height.

An evaluation was performed 25 days after the establishment of the experiment to count explants with fungal contamination, with bacterial contamination, with bud necrosis, discarded by contamination and/or necrosis and/or absence of sprouting, with sprouted buds, and number of shoots per explant. Data were submitted to analysis of variance and the means were compared using the Duncan test at $5 \%$ level of error probability.

\section{Results and discussion}

\section{Experiment I}

From the analysis of the data from experiment I, no significant interaction was identified between the factors removal of leaf residues and composition of the introduction medium, in any of the evaluated variables.

Bacterial contamination was not detected in the treatments from experiment I, while fungal contamination occurred with a significant difference between them (Table 2). The treatment with explants subjected to removal of leaf residues and deposited in liquid introduction medium did not present fungal contamination, making the means of contaminated explants in the other treatments significantly higher when compared to the latter, including the treatment whose explants were not subjected to removal of leaf residues and deposited as well in liquid introduction medium (36\%), as shown in Table 2.

These results indicated that leaf residues would act as a physical barrier to the absorption of Derosal $500 \mathrm{SC}^{\circledR}$ and Chloramphenicol in the node region, which was facilitated after their removal with scalpel both by allowing direct contact between the tissues of said region with said antimicrobial agents present in the liquid medium and by favoring the penetration of the fungicide and antibiotic from wounds caused during the mechanical removal of leaf residues. The statement is based on the fact that, according to Liese (1985), any lateral movement of liquids in the internodes is reduced because their epidermis is formed by two cell layers in which the innermost is highly lignified, and the outermost, covered by a cutinized membrane, so that penetration pathways occur in the basal section of the stems and to a lesser extent in the leaf scar region. In this place, according to Banik (2015), the region below the node presents meristematic cells responsible for intercalar growth, which facilitates the flow of liquids, given the lower lignification of tissues.

Table 2 - Avareges $^{(*)}$ and respectives percentages of explants with fungal contamination (Fungus), with sprouted buds (Sprouting), number of sprouts per bud (Sprouts/Bud) and explants sent to multiplication phase (Multiplication) 25 days after release of experiment $\mathrm{I}$.

\begin{tabular}{|c|c|c|c|c|c|c|c|c|}
\hline \multirow{2}{*}{ Treatmens } & \multicolumn{2}{|c|}{ Fungus } & \multicolumn{2}{|c|}{ Sprouting } & \multicolumn{2}{|c|}{ Sprouts/Bud } & \multicolumn{2}{|c|}{ Multiplication } \\
\hline & Mean & $\%$ & Mean & $\%$ & Mean & $\%$ & Mean & $\%$ \\
\hline $\begin{array}{l}\text { - Explants without removal of leaf } \\
\text { residues in semi-solid introduction } \\
\text { medium }\end{array}$ & $2.20 \mathrm{a}$ & 44 & $4.00 \mathrm{a}$ & 80 & $2.20 \mathrm{a}$ & - & $2.80 \mathrm{a}$ & 56 \\
\hline $\begin{array}{l}\text { II - Explants without removal of leaf } \\
\text { residues in liquid introduction medium } \\
\text { III - Explants with removal of leaf }\end{array}$ & $1.80 \mathrm{~b}$ & 36 & $3.20 \mathrm{a}$ & 64 & $2.20 \mathrm{a}$ & - & $2.80 \mathrm{a}$ & 56 \\
\hline $\begin{array}{l}\text { residues in semisolid introduction } \\
\text { medium }\end{array}$ & $2.10 \mathrm{ab}$ & 42 & $3.80 \mathrm{a}$ & 76 & $1.30 \mathrm{a}$ & - & $2.20 \mathrm{~b}$ & 44 \\
\hline $\begin{array}{l}\text { IV - Explants with removal of leaf } \\
\text { residues in liquid introduction medium }\end{array}$ & $0.00 \mathrm{c}$ & 0 & $2.40 \mathrm{a}$ & 48 & $0.70 \mathrm{~b}$ & - & $1.00 \mathrm{c}$ & 20 \\
\hline CV (\%) & 10.82 & & 16.80 & & 9.18 & & 7.41 & \\
\hline
\end{tabular}

${ }^{(*)}$ Averages transformed by $\sqrt{x+1}$ for analysis. The original values presented followed by the same letter, in the same column, did not differ significantly between them by the Duncan test $(p>0.05)$. C.V $(\%)$ - Coefficient of variation 
It is worth mentioning that the percentages of fungal contamination observed in treatments II (36\%) and IV (0\%), whose explants were deposited in liquid introduction medium, although showing a significant difference between them, tended to be smaller than those recorded in treatments I (44\%) and III (42\%), in which the explants were deposited in semi-solid introduction medium (Table 2), a fact that may be justified by the absence of the fungicide in the culture medium, demonstrating that the use of semi-solid introduction medium with only half of the salt concentration and without sucrose does not represent a viable technique for considerably reducing fungal contamination.

The results are in agreement with those found by Torres et al. (2016a), who, when testing the composition of different culture media for the introduction phase of the in vitro micropropagation of $B$. vulgaris, found no significant difference in the fungal contamination using MS medium with half the salt concentration (82\% of contaminated explants) compared to that found in MS medium with the total concentration (84.7\% of contaminated explants) and although there was significantly less contamination when using MS medium without sucrose (67.3\%) compared to MS medium with sucrose (99\%), still, its absence alone did not result in a substantial reduction of the contamination, proving the need to use more than one strategy to reduce contamination in the said phase.

The trend of lower percentage of fungal contamination detected in the treatment in which explants had leaf residues mechanically removed with a scalpel and were deposited in liquid medium in relation to that in which removal was not proceeded (Table 2) signaled the possibility that, in part, the site consisting of such residues still attached to the leaf scar would be a source of protection for fungal structures, being destroyed after removal. The affirmation is based on the fact that Torres et al. (2016a), when studying the effect of the bud position on the primary branch on the contamination and sprouting of nodal segments of B.vulgaris, observed that in $91 \%$ of the explants, regardless of the bud position in the branch, mycelium formation started from the node region, which may indicate that this is a site of infection in which fungal structures persist even after the natural fall of the leaves covering the buds. still on this issue, Banik (2015) states that this is a region where there are meristematic cells below the node and the emission of hyphae from fungal structures present inside the tissues is facilitated by the lower lignification of cell walls.

The species Bipolaris maydis (Y. Nisik. \& C. Miyake) Shoemaker cited by Mohanan (1994) as a causal agent of bamboo leaf blight is also described by Agrios (2005) to cause southern corn leaf blight in corn (Zea mays L.) and the said author reports that some races of the fungus also attack the stalks, leaf sheaths, ear husks, shanks, ears and cobs from which spores are released and fungal structures may be present.
Thus, in B. vulgaris, despite the absence of symptoms, the possibility of the presence of fungal structures in the leaves covering the buds of the branches and their permanence in the respective residues after manual removal is not ruled out. One fact that reinforces this statement is that Hyde et al. (2002) classified most of the bamboo fungi as non-pathogenic and, thus, the absence of symptoms would not indicate the absence of colonized tissues because even in the case of phytopathogenic species, it is not impossible to have infected tissues without symptoms.

Kumar et al. (2002) cite, in relation to Bipolaris sorokiniana Sacc. In Sorok., etiological agent of helminthosporiosis in wheat (Triticum aestivum L.), that under low light conditions, the fungus colonizes the host tissues intercellularly without causing visible damage. In the case of $B$. vulgaris, in the present research, it should be emphasized that the primary branches, donor of nodal segments, were obtained in the middle third of stems, where shading was a constant condition, thus the absence of symptoms in the leaves covering the buds could also occur and even then the tissues could be infected.

Removal of leaf residues alone, although favoring the elimination of fungal structures present therein, did not result in a significant reduction in fungal contamination, since in the case of semi-solid introduction medium without Derosal $500 \mathrm{SC}^{\circledR}$ and Chloramphenicol, the percentage of explants contaminated when the residues were removed (44\%) did not differ significantly from the percentage recorded in explants where the residues were not eliminated (42\%) and also deposited in semi-solid medium (Table 2). The need to use more than one contamination control technique was proven when no fungal contamination was observed in treatment IV, in which leaf residues were removed and explants were deposited in liquid medium, and in treatment II, where such residues were not removed and explants were also deposited in liquid medium, the percentage of contamination being $36 \%$; in this case, the difference resulted from the use of fungicide added to the culture medium.

Sprouting did not present significant differences between the treatments, ranging from 48 to $80 \%$ (Table 2), and the percentage reached in the treatment corresponding to explants without removal of leaf residues and deposited in semi-solid introduction medium (80\%) was close to that achieved by Torres et al. (2016b), who recorded sprouting percentage from 90 to $100 \%$ of the buds corresponding to the range from the fourth to the eighth position in the primary branch of $B$. vulgaris. The high sprouting percentages found in the present study confirmed what is reported by Devi \& Sharma (2009) for Arundinaria callosa Munro, Mudoi et al. (2014) for Bambusa nutans Wall. ex. Munro, and Torres et al. (2016b) for B. vulgaris, that the highest sprouting percentage is obtained when using as nodal segments those whose buds occupy 
the most central position in the branches.

The mean number of shoots per bud differed between the treatments, being significantly lower in that in which explants were subjected to removal of leaf residues and deposited in liquid introduction medium, of approximately one per bud, in relation to the others that had more than one per bud (Table 2). Similar results regarding the differences between the treatments were detected in the variable corresponding to the number of explants destined to the multiplication stage (explants sprouted and free of contamination). In the case of this variable, the average was significantly lower in the treatments corresponding to explants subjected to removal of leaf residues and deposited in liquid introduction medium $(20 \%)$ or in semi-solid introduction medium (44\%), which differed from each other, as well as were significantly smaller when compared to treatments in which leaf residues were not removed and explants were deposited in liquid or semisolid medium (56\% in both cases) (Table 2) and, for this reason, they were selected to compose the experiment II.
The reason for such results can be attributed to the removal of residues, which, although carefully performed, may have stimulated reactions in the tissues that negatively interfered in the process of bud development, reducing the number of shoots per bud. The assertion is based on the statement of Banik (2015), that injuries on the bamboo stem induce parenchyma cells to produce phenolic compounds in small concentrations, causing reactions to injury in the form of tyloses present in the metaxylem, protoxylem, and sieve tube elements compromising the viability of the tissues. Such a reaction may have been stimulated by injuries caused by the scalpel.

\section{Experiment II}

From the analysis of the data from experiment II, no significant interaction was identified between the thermal treatment and the composition of the introduction medium in any of the evaluated variables. The averages of each variable are found in Table 3.

Table 3 - Averages and respective percentages of explants with: fungal contamination (FC), bacterial contamination (BC), necrosis on bud (NB), discarded caused by contamination and/or necrosis and/or no sprouting, sprouted bud and number of sprouts per bud 25 days after release of experiment II.

\begin{tabular}{|c|c|c|c|c|c|c|c|}
\hline Treatments & Parameter & $\mathrm{FC}$ & $B C$ & NB & Discarded & Sprouting & Sprouts/Bud \\
\hline \multirow{2}{*}{$\begin{array}{l}\text { I- without thermotherapy } \\
\text { and semi-solid medium } \\
\text { without Derosal } 500 \mathrm{SC}^{\circledR} \\
\text { and Chloramphenicol }\end{array}$} & Mean & - & - & - & - & - & - \\
\hline & Perc. (\%) & - & - & - & - & - & - \\
\hline \multirow{2}{*}{$\begin{array}{l}\text { II- with thermotherapy and } \\
\text { semi-solid medium } \\
\text { without Derosal } 500 \text { SC }^{\circledR} \\
\text { and Chloramphenicol }\end{array}$} & Mean & *1.0 ab & $2.4 \mathrm{a}$ & $5.0 \mathrm{a}$ & $5.0 \mathrm{a}$ & $0 \mathrm{~b}$ & $0.0 \mathrm{~b}$ \\
\hline & Perc. (\%) & 20 & 48 & 100 & 100 & 0 & - \\
\hline \multirow{2}{*}{$\begin{array}{l}\text { III- without thermotherapy } \\
\text { and liquid medium with } \\
\text { Derosal } 500 \mathrm{SC}^{\circledR} \text { and } \\
\text { Chloramphenicol }\end{array}$} & Mean & $1.4 \mathrm{a}$ & $0.2 \mathrm{c}$ & $1.2 \mathrm{~b}$ & $2.4 \mathrm{~b}$ & $4.2 \mathrm{a}$ & $3.2 \mathrm{a}$ \\
\hline & Perc. (\%) & 28 & 4 & 24 & 48 & 84 & - \\
\hline \multirow{2}{*}{$\begin{array}{l}\text { IV- with thermotherapy } \\
\text { and liquid medium without } \\
\text { Derosal } 500 \mathrm{SC}^{\circledR} \text { and } \\
\text { Chloramphenicol }\end{array}$} & Mean & $0.6 a b$ & $1.2 \mathrm{~b}$ & $5.0 \mathrm{a}$ & $5.0 \mathrm{a}$ & $0 \mathrm{~b}$ & $0.0 \mathrm{~b}$ \\
\hline & Perc. (\%) & 12 & 24 & 100 & 100 & 0 & - \\
\hline \multirow{2}{*}{$\begin{array}{l}\text { V- with thermotherapy } \\
\text { and liquid medium with } \\
\text { Derosal } 500 \mathrm{SC}^{\circledR} \text { and } \\
\text { Chloramphenicol }\end{array}$} & Mean & $0.0 \mathrm{~b}$ & $0.2 \mathrm{c}$ & $4.8 \mathrm{a}$ & $5.0 \mathrm{a}$ & $0 \mathrm{~b}$ & $0.0 \mathrm{~b}$ \\
\hline & Perc. (\%) & 0 & 4 & 96 & 100 & 0 & - \\
\hline \multirow{2}{*}{$\begin{array}{l}\text { VI- without thermotherapy } \\
\text { and liquid medium without } \\
\text { Derosal } 500 \mathrm{SC}^{\circledR} \text { and } \\
\text { Chloramphenicol }\end{array}$} & Mean & - & - & - & - & - & - \\
\hline & Perc. (\%) & - & - & - & - & - & - \\
\hline C.V.(\%) & & 27.4 & 18.5 & 8.4 & 8.2 & 7.1 & 6.5 \\
\hline
\end{tabular}

*Averages transformed by $\sqrt{x+1}$ for analysis. The original values presented followed by the same letter, in the same column, did not differ significantly between them by the Duncan test $(p>0.05)$. C.V.(\%) - Coefficient of variation. 
Treatments I and VI with explants not subjected to thermal treatment, deposited in semi-solid medium and in liquid medium without Derosal $500 \mathrm{SC}^{\circledR}$ and Chloramphenicol, respectively, presented 96\% and $99 \%$ fungal contamination seven days after launching the experiment and all replicates of these treatments presented fungal and bacterial contamination after 14 days, hence with no data evaluation 25 days after the launch of the experiment.

The results showed that non-exposure of explants to thermotherapy or deposition of explants in antibiotic- and fungicide-free introduction medium allowed the expression of contaminations in high percentages by the absence of physical or chemical barriers imposed to the microbial growth. This agrees with the results described in published protocols for the in vitro culture of different bamboo species, in which the authors, aiming to obtain sprouted and healthy explants, made use of a technique to reduce microbial contamination in terms of the pretreatment of explants and/or changes in the composition of the culture medium (Jiménez et al., 2006; Ramanayake et al., 2006; Ali et al.; 2009; Arya \& Arya, 2009; Sharma \& Sarma, 2011; Anand et al., 2013; Jha, et al. 2013; Malini \& Anandakumar, 2013; Sharma \& Sarma, 2013; Mudoi et al., 2014; Generoso, 2014; Wadaktar, et al., 2014; Ribeiro et al. 2016; Torres et al., 2016a), proving that microbial contaminations are one of the main limiting factors for in vitro culture techniques, as cited by Msogoya et al. (2012). The results obtained, however, disagree with those found by Sharma \& Sarma (2014), who, studying the micropropagation of Bambusa pallida (L.) Voss., obtained $80 \%$ of explants free from contamination and $100 \%$ sprouted explants without mentioning the use of chemical or physical methods to control the contaminations.

The fungal contamination did not differ significantly between treatments II, III and IV, ranging from 12 to $28 \%$. Notwithstanding, significant differences were observed between treatments III (28\%) and V $(0 \%)$ (Table 3), which can be attributed to the joint effect of thermotherapy and addition of fungicide and antibiotic to the culture medium, since in treatment III, explants were not subjected to $50{ }^{\circ} \mathrm{C}$ for $20 \mathrm{~min}$ and in treatment $\mathrm{V}$, explants were subjected to said thermal treatment and deposited, as in treatment III, in liquid introduction medium added with Derosal $500 \mathrm{SC}^{\circledR}$ and Chloramphenicol. Yet in treatment IV (12\% contamination), in which the explants were subjected to thermotherapy and deposited in liquid introduction medium without Derosal $500 \mathrm{SC}^{\circledR}$ and Chloramphenicol, the percentage of contamination did not differ from that found in treatments III (28\%) and V $(0 \%)$.

The fungal contamination value (28\%) recorded in treatment III (Table 3) was below that found by Ramanayake et al. (2006), equal to $85 \%$ in a research on the micropropagation of Bambusa vulgaris 'Striata' (Lodd. ex Lindl.) Gamble, using culture medium supplemented with $0.1 \%$ Benlate $^{\circledR}$, and above that found by Ribeiro et al. (2016), who detected a contamination percentage close to $10 \%$ when maintaining explants of $B$. vulgaris in introduction medium without sucrose, and Torres et al. (2016a), who, after 23 days, detected $12 \%$ of fungal contamination in $B$. vulgaris explants maintained for seven days in introduction medium with the same concentrations of Derosal $500 \mathrm{SC}^{\circledR}$ and Chloramphenicol used in the present research.

The effectiveness of thermotherapy using the $50{ }^{\circ} \mathrm{C}-20 \mathrm{~min}$ binomial in reducing fungal contaminations is cited by Sponholz et al. (2004), who obtained a reduction of $85 \%$ of injured area in banana fruits (Musa L. spp.) affected by Colletotrichum musae Berk \& Curtis, and by Brito et al. (2008), in postharvest control of Aspergillus Micheli sp. and Fusarium Link sp. in Spondias fruits (Spondias mobin L.), observing less than $10 \%$ incidence for the first and no incidence for the second fungal genus. In the present research, although the percentage of fungal contamination was null, the temperature-time binomial had a negative influence on sprouting, since in all the treatments in which it was used (treatments II, IV and V), the sprouting percentage was zero, while in treatment III, in which thermotherapy was not used, the sprouting percentage was significantly higher (84\%) despite the contamination percentage of $28 \%$ (Table 3 ).

The absence of sprouting obtained in the present research using the temperature-time binomial tested is contrary to the principle on which the thermotherapy is based, as cited by Groedeau \& Samson (1994), according to which it is a technique whose premise is the death of parasitic organisms in regimes of temperature and time that practically do not cause injuries to the host.

The absence of sprouting in treatments II, IV and $\mathrm{V}$, in which thermotherapy was used (Table 3), can be justified as a result of tissue damage by the exposure time (20 minutes) of explants to the water heated at the described temperature $\left(50{ }^{\circ} \mathrm{C}\right)$, which caused the death of the tissues represented by the number of explants with bud necrosis, whose means were significantly higher in these treatments, with percentages of $96 \%$ (treatment V) and 100\% (treatments II and IV), when compared to treatment III (24\%), in which thermotherapy was not used (Table 3).

Bud necrosis as damage caused by thermotherapy resulting in absence of sprouting was justified by Urashima \& Grachet (2012) as a result of the tissue susceptibility to thermal injury as a function of tissue age. When studying the effect of the technique on the sprouting of buds of three different sugarcane varieties, these authors identified that there is greater susceptibility in apical and median buds compared to basal ones to thermal injury when subjected to $50{ }^{\circ} \mathrm{C}$ for 2 hours, that is, the younger the bud, the greater the damage caused. In the case of $B$. vulgaris, an indication that reinforces the possibility of greater susceptibility of younger buds to thermal injury is that the occurrence of a higher percentage of bud necrosis according to their age, even without the use of 
thermotherapy, has already been verified by Torres et al. (2016b), when studying the effect of the position of nodal segments on the primary branch on contamination and sprouting. The aforementioned authors identified that at 21 days, nodal segments (of the same length and introduced in semi-solid introduction medium of the same composition as the present study) containing the youngest buds showed $10 \%$ necrosis. Thus, the adoption of thermotherapy may have potentiated the expression of the symptom that naturally occurs when explants are subjected to the procedures of the introduction phase. In the present study, we used explants with buds that occupied from the fourth to the eighth position in the branch.

The mean number of explants with bacterial contamination in treatment II (48\%) was significantly higher compared to the others (Table 3), which may be justified by the absence of antibiotic added to the culture medium. When Chloramphenicol was added to the medium, as in treatments III and V, bacterial contamination was significantly lower (4\%) (Table 3) regardless of whether or not the explants were subjected to thermotherapy, demonstrating that the technique alone was not effective in reducing bacterial contamination under the conditions of the experiment.

The mean number of explants discarded in treatment III (48\%) was significantly lower compared to treatments II, IV and V (Table 3). Treatment III was the only one whose explants had sprouted buds (84\%) and $56 \%$ of the explants initially belonging to this treatment were healthy and sprouted, being destined to the multiplication phase (Table 3).

The percentages of fungal contamination obtained in treatment II, corresponding to the explants without removal of leaf residues and deposited in liquid introduction medium with Derosal $500 \mathrm{SC}^{\circledR}$ and Chloramphenicol (36\%) from experiment I, and treatment III, corresponding to the explants not subjected to thermotherapy and deposited in liquid introduction medium with Derosal $500 \mathrm{SC}^{\circledR}$ and Chloramphenicol (28\%) from experiment II, were lower than the contamination percentage of $52 \%$ observed by Jiménez et al. (2006) in the in vitro micropropagation of Guadua angustifolia Kunth, using in the pretreatment of explants Extran with streptomycin sulfate (Agri-mycin $\left.{ }^{\circledR}\right)$ and Benomyl associated with disinfestation with sodium hypochlorite solution.

The percentage of fungus-contaminated explants in treatments II and III from the respective experiments I and II were also equal to and lower than the contamination percentages of $36 \%$ and $48 \%$ reported by Generoso (2014) when using culture medium containing or not sodium hypochlorite, respectively, and were lower than the results described by Malini \& Anandakumar (2013) when pre-disinfestation of $B$. vulgaris explants was performed only with $0.15 \%$ mercury chloride solution for 15 minutes, with $64 \%$ of contamination.

The results obtained in treatments II and III from experiments I and II, respectively, regarding the reduction of fungal contamination, showed that the use of Carbendazim-based fungicides in the pretreatment and their inclusion in the introduction medium should be considered promising for reducing contaminations. This agrees with Torres et al. (2016a), who showed a significant reduction of contamination in the introduction and establishment of the in vitro micropropagation of $B$. vulgaris when using already in pretreatment the solution of Derosal $500 \mathrm{SC}^{\circledR}$ (4 $\mathrm{mL} \mathrm{L}^{-1}$ ) and Chloramphenicol (200 $\mathrm{mg} \mathrm{L}^{-1}$ ) for immersion of explants for $30 \mathrm{~min}(77.7 \%$ of contamination), when compared to pretreatment without immersion in said solution (87.7\%). The authors also verified a significant reduction in fungal contamination (12\%) when using in pretreatment the said solution combined with the addition of these antimicrobials, in the same concentrations, to the introduction medium with the same constitution described in the aforementioned treatments of the present research, which can be attributed to the increased exposure time of plant tissues and microbial structures to the systemic action of the active principle of the fungicide.

Published works on the in vitro micropropagation of bamboo species usually mention the use of Carbendazim-based products only in pretreatment, without, however, comparing the contamination percentage reached with other treatments, such as Sharma \& Sarma (2011) for Bambusa balcooa Roxb., Jha et al. (2013) for Dendrocalamus hamiltonii Munro, and Sharma \& Sarma (2013) for Bambusa tulda Roxb., in which immersion of the explants is described for 15 minutes in $0.5 \%$ Bavistin ${ }^{\circledR}$ solution, and $0.1 \%$ Bavistin ${ }^{\circledR}$ solution in the case of Anand et al. (2013) for Bambusa bambos (L.) Voss.

The results obtained considering the bud sprouting in treatment II (84\%) from experiment I and treatment III (64\%) from experiment II were promising. Sharma \& Sarma (2011), in the micropropagation of $B$. balcooa, reported that the breaking of bud dormancy and shoot emission depend on the explant condition, seasons and growing conditions. In fact, Anand et al. (2013) observed that in explants of $B$. bambos, the sprouting percentage was $93 \%$ in spring, but during the rainy season, although it was similar, the contamination percentage was high. Ramanayake et al. (2006) recorded $50 \%$ sprouting and $85 \%$ microbial contamination in explants of $B$. vulgaris 'Striata' collected during the monsoon season. Mudoi et al. (2014) described maximum bud sprouting and shoot proliferation of $B$. nutans during early autumn (45\%), but in winter, only $35.02 \%$ dormancy breaking was recorded with a minimum number of sprouted buds.

The explants in the present study were collected in the summer (dry season) and the maximum sprouting described in treatment II (84\%) from experiment I and treatment III (64\%) from experiment II can be considered close to those obtained by Torres et al. (2016a) with micropropagation of $B$. vulgaris, in which 
there was $88 \%$ sprouting of the explants collected in the dry season by adding to the introduction medium the same concentration of Derosal 500 SC $^{\circledR}$ used in the present research, and by Ramanyake et al. (2006) in the micropropagation of $B$. vulgaris 'Striata', with $50 \%$ sprouting when using $0.1 \%$ Benlate $^{\circledR}$ in the culture medium.

The percentages of fungal contamination and sprouting and the mean number of shoots per bud obtained in treatment II from experiment I (36\%, 64\%, approximately two, respectively) and in treatment III from experiment II (28\%, 84\%, approximately three, respectively) have demonstrated considerable efficacy in reducing microbial contamination with minimal interference in bud sprouting and shoot emission.

\section{Conclusions}

The chemical method corresponding to the treatment in which explants were maintained in introduction medium added with Derosal $500 \mathrm{SC}^{\circledR}$ (4 mL L-1) and Chloramphenicol (200 mg L-1) for seven days proved to be effective in reducing microbial contamination in the in vitro culture of $B$. vulgaris, ensuring a considerable sanitary level and viable shoots to be sent to the multiplication stage.

The physical methods corresponding to the removal of leaf residues in the leaf scar region and the submission of explants to thermotherapy using the $50^{\circ} \mathrm{C}-20 \mathrm{~min}$ binomial alone were not effective in reducing the microbial contamination of explants of $B$. vulgaris, in addition to interfering with the number of explants destined for the multiplication phase.

\section{Acknowledgements}

The authors thank the Ministry of Science, Technology, Innovation and Communications (MCTIC) and the National Council for Scientific and Technological Development (CNPq) for the financial support.

\section{References}

Agrios GN (2005) Plant diseases caused by fungi. In: Agrios GN (ed) Plant Pathology. 5 ed ELSEVIER, cap. 11. p. 385-614.

Ali AH, Nirmala C, Badal T, Sharma ML (2009) In vitro organogenesis and simultaneous formations of shoots and roots from callus in Dendrocalamus asper. Horticulture 6:31-40.

Amorin L, Bergamim Filho A (2006) Conceitos básicos de manejo de doenças quiescentes em frutas. Anais da Academia Pernambucana de Ciência Agronômica 3:119-138.

Anand M, Brar J, Sood A (2013) In Vitro Propagation of Edible Bamboo Bambusa bambos and Assessment of Clonal Fidelity through Molecular Markers. Journal of Medical and Bioengineering 2(4):257-261.
Arya ID, Arya S (2009) Propagation of Bamboos through Culture Technology and Field Plantation. Horticulture 6:131-143.

Banik RL (2015) Morphology and Growth. In.: Liese W, Köhl M Bamboo: the plant and its uses. London: Springer, cap. 3, p. 43-89.

Brito $\mathrm{CH}$, Costa NV, Batista JL, Nascimento LC, Oliveira HD, Barreto ES (2008) Termoterapia para controle de patógenos em pós-colheita em frutos de cajazeira. Acta Scientiarum. Agronomy 30(1):19-23.

Devi WS, Sharma GJ (2009) In vitro propagation of Arundinaria callosa Munro- an edible bamboo from nodal explants of mature plants The Open Plant Science Journal 3:35-39.

Generoso AL (2014) Caracterização morfológica e cultivo in vitro de espécies de bambu. Universidade Estadual Norte Fluminense Darcy Ribeiro (Dissertação de Mestrado em Genética e Melhoramento de Plantas).

Grondeau C, Samson R (1994) A review of thermotherapy to free plant materials from pathogens, especially seeds from bacteria. Critical Reviews in Plan Sciences 13(1):57-75.

Hyde KD, Zou D, Dalisay, T (2002) Bambusicolous Fungi: A Review. Fungal Diversity 9:1-14

Jha A, Das S, Kumar B (2013) Micropropagation of Dendrocalamus hamiltonii through nodal explants. Global Journal of Bio-Science and Biotechonolgy 2(4):580-582.

Jiménez VC, Castillo J, Tavares E, Guevara E, Montiel M (2006) In vitro propagation of the neotropical giant bamboo. Guadua angustifolia Kunt, trough axillary shoot. Plant Cell Tissue Organ Culture 86:389-395.

Kumar J, Schäfer P, Hückelhoven R, Lagen G, Baltruschat $H$, Stein $E$, Nagarajan S, Kogel $K$ (2002) Bipolaris sorokiniana, a cereal pathogen of global concern: cytological and molecular approaches towards better control. Molecular Plant Pathology 3(4):185-195.

Liese W (1985) Anatomy and properties of bamboo. In: Proceedings of the International Bamboo Workshop. China:196-208.

Malini N, Anandakumar CR (2013). Micropropagation of bamboo (Bambusa vulgaris) through nodal segment. International Journal of Forestry and Crop Improvement 4(1):36-39.

Mendes MAS, Lima PMMP, Fonseca JNL, Santos MF (2001). Erradicação de Fusarium oxysporum em sementes de alfafa utilizando termo e quimioterapia. Fitopatologia Brasileira 26(2):148-152. 
Mohanan C (1994) Diseases in Bamboos and Rattans in Kerala. Thrissur:Kerala Forest Research Institute. 120 p. (KFRI Research Report 98).

Mudoi KD, Saikia SP, Bortharkhur M (2014) Effect of nodal positions, seasonal variations, shoot clump and growth regulators on micropropagation of commercially important bamboo, Bambusa nutans Wall. Ex. Muro. African Journal of Biotechnology 19(19):1961-1972.

Murashige T, Skoog F (1962) A revised medium for rapid growth and bioassays with tobacco tissue culture. Physiologia Plantarum 15:473-497.

Msogoya T, Kaniagha H, Mutigitu J, Kulebelwa M, Mamiro D. (2012) Identification and Management of Microbial Contaminants of Banana in vitro Cultures. Journal of Applied Biosciences 55:39873994.

Nath AJ, Gitasree Das, Kumar Das A (2008) Vegetative phenology of three bamboo species in subtropical humid climate of Assam. Tropical Ecology 49(1):85-89.

Ramanayake SMSD, Meemaduma VN, Weerawardene TE (2006) In vitro shoot proliferation and enhancemenet of rooting for the largescale propagation of yellow bamboo (Bambusa vulgaris 'Striata'). Scientia Horticulturae 110:109$-113$.

Ribeiro AS, Brondani GE, Tormen GCR, Figueiredo AJR (2016) Cultivo in vitro de bambu em diferentes sistemas de propagação. Nativa, $4(1): 15-18$.

Sharma B, Gatóo A, Ramage MH (2015) Effect of processing methods on the mechanical properties of engenireed bamboo. Construction and Building Materials 83:95-101.

Sharma P, Sarma KP (2011). In vitro propagation of Bambusa balcooa for a better environment. In: International Conference on Advances in Biotechnology and Pharmaceutical Sciences, 2011, Bangkok. Proceedings... Bangkok: Planetary Scientific Research Centre, p. 248-252.
Sharma P, Sarma KP (2013) In Vitro Propagation of Bambusa tulda: An Important Plant for Better Environment. Journal of Environmental Research and Development 7(3):1216-1223.

Sharma P, Sarma KP (2014). In vitro propagation of Bambusa pallida on commercial scale in Assam, India. Journal of Environmental Research and Development 8(4) 895-902.

Sponholz C, Batista UG, Zambolim L, Salomão LCC, Cardoso AA (2004) Efeito do tratamento hidrotérmico e químico e frutos de Banana 'Prata' no controle da antracnose em pós-colheita. Fitopatologia Brasileira 29(5):480-485.

Tokeshi H (1997). Doenças da cana-de-açúcar. In: Kimati $H$, Amorim L, Bergamin Filho A, Camargo LEA, Rezende JAM (ed.) Manual de Fitolapologia Volume 2: Doenças das Plantas Cultivadas, 3ed. São Paulo: Agronômica Ceres, cap. 19, p. 207-225.

Tomazello Filho M, Azzini (1987) A. Estrutura econômica, dimensões de fibras e densidade básica de colmos de Bambusa vulgaris Schrad. IPEF 36:43-50.

Torres, GRC, Houllou LM, Souza RA (2016a) Control of contaminants during introduction and establishment of Bambusa vulgaris in vitro. Research in Biotechnology 7:58-67.

Torres GRC, Santos PVS, Souza RA, Dantas PVP (2016b). Efeito da posição de segmentos nodais sobre a contaminação e brotação na micropropagação do bambu. Ciência \& Tecnologia: Fatec-JB 8:1-15.

Urashima AS, Grachet NG (2012) Métodos de detecção de Leifsonia xyli subsp. xyli e efeito da termoterapia na brotação das gemas de diferentes variedades de cana-de-açúcar. Tropical Plant Pathology, 37(1):57-64.

Wadaktar CM, More NV, Patil VV (2014) Initiation of suspension culture and somatic embryogenesis to plant regeneration in multipurpose bamboo (Dendrocalamus tulda). Indian Journal of Applied Research 4(1):149-151. 